\title{
From Visionary to Functionary: Representations of Irish intellectuals in the debate on "Europe"
}

\section{Katy Hayward}

\section{Q OpenEdition \\ 1 Journals}

\section{Electronic version}

URL: http://journals.openedition.org/etudesirlandaises/1650

DOI: 10.4000/etudesirlandaises. 1650

ISSN: 2259-8863

\section{Publisher}

Presses universitaires de Rennes

\section{Printed version}

Date of publication: 30 September 2009

Number of pages: $87-100$

ISBN: 978-2-7535-0982-5

ISSN: 0183-973X

\section{Electronic reference}

Katy Hayward, «From Visionary to Functionary: Representations of Irish intellectuals in the debate on "Europe" », Études irlandaises [Online], 34.2 | 2009, Online since 30 June 2011, connection on 03 May 2019. URL : http://journals.openedition.org/etudesirlandaises/1650 ; DOI : 10.4000/ etudesirlandaises.1650

This text was automatically generated on 3 May 2019.

(c) Presses universitaires de Rennes 


\title{
From Visionary to Functionary: Representations of Irish intellectuals in the debate on "Europe"
}

\author{
Katy Hayward
}

\section{Introduction}

1 The defeat of Ireland's first referendum on the Treaty of Lisbon in June 2008 presaged by a few months the global cataclysm that sent ruinous tremors through the country's economic, political, and social bedrock. This crisis turned Ireland's remarkable entrenchment in the globalised system on its head, simultaneously revealing both the dangers and the necessity of supranational cooperation. The very fact of the second referendum on the same treaty some sixteen months later served as a cold reminder to the Irish electorate that membership of the European Union remains an imbalanced affair: Ireland's need for the EU will always exceed its influence upon it. The result of Lisbon I may be understood in part as Irish voters taking the rare opportunity to counter this inequity in one grand gesture, but the national circumstances of the Lisbon II referendum once again brought realism to the fore. This tension between pragmatism and idealism is worth uncovering here precisely because it has become apparent in Irish debates about "Europe" only relatively recently. Until around the turn of this century, Ireland's EU membership was successfully presented as fortuitously both essential and beneficial. In this article, I argue that the debate on EEC accession in Ireland originally enabled intellectual contributions to combine "visionary" concepts of the ideal "Europe" with the "functionary" requirements of joining; in fact, the idealised notions of integration served in some ways to obfuscate in the public mind the actualities of EEC membership. 
2 This mixing of "functionary" and "visionary" was particular evident in - and facilitated by - intellectual discourses originating from the dominant conceptual frameworks for national political development and debate at the time of Irish accession to the EEC, namely Catholicism and nationalism. In this sense, after Bourdieu and Eisenstadt, we are considering here the representation of intellectuals in the (re)production of Irish cultural and social values as they participate in the symbolic and institutional frameworks of the nation ${ }^{1}$. Beyond this, are questions of how intellectuals therefore served to legitimise both the state and the state's seceding of sovereignty - reinterpreting tradition at the same time as appearing to reinforce it.

The intellectual construction of the Irish nation-state was certainly integral to the imagining of "European Community" in Ireland. Indeed, mainstream political and intellectual discourses presented European integration in terms of the fulfilment of Irish nationalism ${ }^{2}$. However, the "visionary" thinking about European integration by Irish intellectuals, so crucial to shaping enthusiasm and support for EU membership in the second half of the twentieth century, had all but disappeared by the first referendum on the Treaty of Nice in $2001^{3}$. Instead, intellectuals play an increasingly "functionary" role in debates about "Europe", in effect supporting the official position of the Irish government without being given much scope for critiquing or elaborating upon it. This shift from "visionary" to "functionary" represents a conglomeration of trends that have together reduced the space for intellectualising European integration in Ireland.

In intellectual analyses in the twentieth century, Fanning summarises, "Europe was viewed as a positive political influence on Ireland, a chance for economic and social uplift 4". But this generally warm approach to integration - aided by the intellectual analyses considered at a later point in this article - was not based on detailed, practical or imaginative consideration of its purpose. Ireland was entering a great unknown when it joined the European Economic Community; indeed, the Irish Minister for European Affairs, Dick Roche, has gone so far as to say that the Irish people and government "had no idea what we were getting into" at the point of accession ${ }^{5}$. Such an "inability to think through the full implications of EEC/EU membership" has continued to feature in Irish political and intellectual discourses on the subject ${ }^{6}$. Patrick O'Mahony and Gerard Delanty argue that this "reveals a society still intoxicated by anticipation rather than sobered by reality". But what makes this "anticipation" quite so engaging and, on occasion, fickle (as the results of the first referendums on the Treaties of Nice and Lisbon imply) is the fact that it is not based on any firm vision of the potential future of Ireland in Europe. The anticipation held by the Irish people - and sustained by intellectual contributions - for European integration is essentially determined by ideal notions of the Irish nation-state. Maurice Goldring has depicted Irish intellectuals as patriots, in love "with an illusionary country and tradition, with an image, with a representation"; what else, he asks rhetorically, "can one be in love with?" Ireland's "vision" of Europe has been but a hazy reflection of this chimera. European integration was (until recent times) presented by the majority of Irish intellectuals as a patriotic venture in the belief that EEC/EU membership offered the framework for the realisation of Irish national ambitions.

5 Thus, European integration has not been a topic of consistent fascination among Ireland's intellectuals because the predominant obsession has been with the nation - its needs, its interests, its identity - and European integration has by and large been discussed in conjunction with this rather than as a supranational project itself. In this article, I will show that contributions from Irish intellectuals in the debate on "Europe" have 
effectively correlated with the dominant (intellectual and political) discourses about the Irish nation-state. Maurice Goldring's insightful description of "personalised intellectualism" in Ireland, whereby contributions to national debates tend to be recalled and assessed in terms of key personalities ${ }^{9}$, is certainly true in relation to the representation of intellectuals in this area. Notwithstanding this, Irish intellectuals have traditionally contributed to public debate about nation-statehood and European integration from within the framework of two tropes integral to mainstream political power and thought in Ireland at the time of accession, these being Catholicism and nationalism. This article considers the representation of intellectuals vis-à-vis the debate about European integration, specifically the "visions" of "Europe" they conjured and how these related to the "function" of supporting EU membership.

\section{Representations of intellectuals in support of integration}

\section{Catholic conceptions of "Europe"}

6 At the time of the creation of the Common Market and, a little later, Ireland's first application to EEC membership in 1961, ecclesiastical influence still weighed heavily in policy-making and public discourse. Intellectual contributions to matters of political, economic and social importance largely centred on the precepts of the Catholic Church (even if they were in opposition to them) and were often made by those speaking from within it, including the numerous professors in the National University of Ireland who were ordained Catholic priests ${ }^{10}$. Bryan Fanning's study of intellectual journals explores the debates that "shaped modern Ireland", most prominent among which (particularly in the mid-twentieth century) are the journals which reflected a form of Catholic social conscience ${ }^{11}$. These included Studies: An Irish Quarterly Review of Letters, Philosophy and Science (founded in 1912), which is published by Jesuits but includes contributors from lay intellectuals (from Patrick Pearse to Garret FitzGerald) as well as clergy, and Christus Rex: An Irish Quarterly Journal of Sociology (1947-1970), which reflected the presence of priests in the humanities and social sciences in Irish universities ${ }^{12}$.

Interest in European integration among Irish intellectuals writing in these journals was present even prior to Ireland's application. This concern was grounded in a sense of the magnitude of the "moment of decision" faced by European countries in the wake of the Second World War, finding themselves "between two new world poles, and [...] subject to the influence and interests of both ${ }^{13}$ ". Speaking in the broadest terms, the Catholic Church did not wish to see Europe become swayed by the influence of either Marxism or American capitalism. Thus, Irish intellectuals writing from a Catholic perspective welcomed the creation of the embryonic European Defence Community in 1952 as enabling nothing less than the survival of "Europe":

[T] he Catholic can remember that what we know to-day as Europe is largely the creation of the Catholic Church... For the Catholic the proposal of a United Europe is, so to say, only putting the clock back... That a Catholic should welcome closer collaboration between European countries and should look with understanding and sympathy upon a properly balanced attempt to recreate unity in Europe is reasonably to be expected ${ }^{14}$. 
embodies the direct connection made between the creation of the European Community and "those ideas and values which have made Europe what Europe was and is," i.e. the moral code and remit of the Catholic $\mathrm{Church}^{15}$. Traditional arguments for European integration made by intellectuals within the cultural apparatus of the Church presented it in terms of a civilising project, the redemption of Europe, the rediscovery of a "social and spiritual heritage ${ }^{16 "}$. This notion was slowly developed and expanded over the 1950s and 1960s - particularly in relation to the concept of European integration as a bulwark against Russian Communism. A fine example of this discourse is a speech given by the Bishop of Clonfert, William J. Philbin, soon after Ireland's first application for EEC membership, which is worth quoting at length:

What is coming to pass has in fact been written about in terms of the Messianic Age... A prototype of what is looked for is found not in the European homogeneity once enforced by Roman arms but in the unity of spirit that was later established among the same peoples by the Christian concept of universal brotherhood. It is believed that the Articles of Association of the E.E.C. were christened as the Treaty of Rome with a view to conveying this implication. In the latter centuries the West has fallen away widely from many of its characterizing beliefs, but its communities have still kept a lowest common measure of faith in their consciousness that the roots of their culture, their elements of cohesion and their chief differences from those who seek to destroy them are grounded in spiritual things. In such thinking we find the deepest moral content of what is happening today in Western Europe ${ }^{17}$.

9 The notion of a return to a simple Christian civilisation in Europe was particularly attractive because it conjured up myths about Ireland's own role in the Dark Ages. This argument was not confined to those speaking on behalf of the Church but was present even in the discourses of high-ranking Irish civil servants, who argued for example that the Irish people "can fairly claim to be foundation members of that post-Roman civilisation which has evolved into the Europe of to-day [...]. We played our fair part in the Christianising and civilising of the barbarian hordes, whose posterity was destined to mould the European heritage into its present context and form ${ }^{18 "}$.

10 This type of "visionary" discourse from intellectual leaders served to reassure the Irish Catholic populace that the creation of a united Europe was both a necessity and an opportunity. Grandiose reflections on the future of this embryonic European community were most present in Irish Catholic intellectual discourse (as depicted in journals such as Studies) in the early period of Ireland's application and accession to the EEC ${ }^{19}$. After this time, apart from a flurry of interest around the creation of European Union in 1989-1992 and the prospect of enlargement in $2004^{20}$, "Europe" became little more than a familiar backcloth to set-pieces on the nation-state (its economy, its neutrality, its identity, etc.) ${ }^{21}$. In general intellectual contributions to the public debate about "Europe" from an overtly Catholic perspective declined in significance after the 1960s, not only due to the wider changes occurring in Irish society at that time but also because Irish thinkers and voters sought more from European integration than the rediscovery of a mythical past.

\section{Nationalist conceptions of "Europe"}

11 Richard Kearney describes Hyde's Gaelic League as a movement to “repossess Ireland's dispossessed culture", and it is apparent that many Irish intellectuals who supported accession to the EEC did so for similar reasons ${ }^{22}$. In a pamphlet setting out the "cultural 
aspects" of Ireland's EEC accession, Tarlach Ó Raifeartaigh, the first Chairman of the Higher Education Authority, refers to Douglas Hyde's arguments for Gaelicisation and draws parallels with his own argument for integration with Europe ${ }^{23}$. The most pressing concerns for Irish nationalist intellectuals for much of the twentieth century were continued dependence on Great Britain, the poor state of the Irish economy, the unsettled existence of Northern Ireland, and the erosion of the integrity of Irish culture. On a "practical" level, accession to the EEC appeared to offer the opportunity to correct the first two of these threats. Some intellectuals then connected the "idealising" of European integration to the other two matters. For example, Garret FitzGerald's book Towards a New Ireland predicted that "such influence as membership of the Community will have is likely to be uniformly directed towards easing that path to a united Ireland ${ }^{24 "}$ ". One way in which this could happen, it was suggested, would be that a heightened appreciation of the points of commonality among those on the island of Ireland would occur through the experience of being in the EEC: "by joining Europe and facing Europe together we might create that sense of unity at home ${ }^{25}$ ".

This (Irish and European) unity was made all the more urgent by the growing sense that "there is a danger of our being somewhat swamped by the all-pervasive Anglo-American culture", and the argument made was that "the more we can reorient ourselves towards Continental influences the more chance we have of resisting Anglo-Americanism ${ }^{26 "}$. European integration thus came to be presented by many as a benign alternative to "our own way of life [...] being greyed out against the background of the mighty mid-Atlantic civilisation ${ }^{27}$ ". Other elements of the case made by nationalist intellectuals for European integration arguing that it offers the chance to preserve the integrity of Irish native culture include: the opportunity to "end provincialism and insularity"; the means to escape "being in various ways at the mercy of our nearest neighbour"; the claim that "a united Ireland could find a better background than is available at present"; intriguingly, the expectation that "close contact with Continental peoples must add to our intellectual stock"; and, in sum, the chance to no longer appear "as that charming but sometimes troublesome little country ${ }^{28}$ ". Given the urgency and greatness of the threat to Irish culture, Ó Raifeartaigh warns, "if we fail to join hands with the Continent... we face eventual total assimilation ${ }^{29 "}$. He concludes by drawing together the pragmatic and idealistic elements of the nationalist case for accession:

Within [the EEC] we could legitimately combine affection for our own Country with a feeling for the wider heritage in which we also share - and at the same time enjoy the bonus of a partial escape from the present economic and cultural nearmonopoly which holds us in its whim ${ }^{30}$.

\section{Representations of intellectuals critical of European integration}

13 In order to get a rounder picture of representations of intellectuals in the debate on "Europe" in Ireland, it is necessary to consider those who speak from a critical position. Many critics of European integration ground their resistance in left-wing political ideals. This is unsurprising given that socialism has been an oppositional and minority position for Irish political actors. The peripheral position of socialist thought in the official conceptualisation of European integration was exacerbated by the fact that the left-wing experienced a deep split on the matter of EEC membership immediately after accession. 
Left-wing intellectual advocacy of European integration in Ireland has an indomitable lead character in the form of the Labour Party's Michael D. Higgins, whose contributions to the "European" debate are among the most innovative and reflective on the proEuropean side, combining support for integration because of what it could become ${ }^{31}$ with a willingness to critique the EU because of its failure to move consistently towards that goal ${ }^{32}$. Outside the Labour Party, most socialist public thinkers in Ireland have written, spoken and acted in opposition to the development of the EU. It is important to note that very few critics from across the political spectrum would describe themselves as forthrightly opposed to European integration as such ; instead they condemn aspects of the European Union as it is currently conceived and developed whilst reserving the possibility that it might yet be altered to become less objectionable.

Some critics of European integration chose to speak from a determinedly independent position, as did Liam de Paor and John De Courcy Ireland. Other academic critics have taken prominent stances in public campaigning in opposition to European treaties (and the dominance of pro-integrationism in Ireland), for example Raymond Crotty, Roy Johnston, Roger Garland and Anthony Coughlan ${ }^{33}$. It is possible to contend that the "antiestablishment" and even "personalised" nature of such activism became far more prominent than the original rationale behind individuals' participation. Today, objections to European integration from intellectual and academic critics often arise as a result of their wariness of globalisation. For example, Peadar Kirby's critique of the Celtic Tiger incorporates a wariness of the economic model underpinned by the $\mathrm{EU}^{34}$, and Andy Storey's criticism of the "neoliberalism" of the EU is tied with his leading role in a nongovernmental organisation for global justice ${ }^{35}$.

There has also always been an enduring element of conservativism in criticism of European integration. For example, prior to accession Bord na Móna chairman, Aodogan O'Rahilly, expressed concerns that, that "if we were going to enter the EEC then our sovereignty would be lost and in a free trade environment we would quickly go under ${ }^{36 "}$. O'Rahilly described his views in retrospect as being those of "an old style Fianna Fáil nationalist" - a comment which reveals quite how significantly Irish official nationalism had changed by the $1960 \mathrm{~s}^{37}$. Other dominant forms of ideology have also changed and been redefined in Ireland, so much so that some of the early arguments made by some intellectuals in support of European integration have since become the preserve of those objecting to it. Desmond Fennell, for example, echoes the type of conservative Catholic cosmopolitanism expressed by Catholic intellectuals in the early days of Ireland's integration into the European Community (see above) but he has a contrastingly negative interpretation of the nature and future of the "postwestern" condition ${ }^{38}$. Notably, Fennell considers himself unusual among Irish intellectuals for being concerned, and free to write, about subjects beyond that of Ireland and the Irish ${ }^{39}$. His outlook might be idiosyncratic compared to mainstream Irish intellectualism, but in many ways he is still speaking to it. What this very brief sketch confirms is that the conception of Irish nationstatehood is at the heart of the debate even in critical approaches to European integration: whether this nation-state be a Celtic Tiger over-dependent on the market economy (as according to Kirby), a government over-enthused with EU sovereigntysharing (as according to Coughlan) or a populace over-whelmed by the "soft totalitarianism" of western governance (as according to Fennell). 


\section{Constraints on the representation of intellectuals in current debates}

\section{Technicalism and pragmatism}

In making the argument that the growing influence of technicalism has inhibited intellectual imagination in the conceptualisation of European integration, I am not belittling the great role the Irish public service has and continues to play in innovation and knowledge in Irish culture and governance. Indeed, many of Ireland's most notable public intellectuals in the twentieth century emanated from the public service, including Conor Cruise O'Brien, Valentin Iremonger, Brian Ó Nualláin [Flann O'Brien, Myles na gCopaleen], and T. K. Whitaker ${ }^{40}$. Academics and policy-makers who attempt to marry intellectual critiques with the technical and bureaucratic dimensions of governing and modernising the nation-state have long been facilitated in doing so by the Institute of Public Administration's journal Administration (founded 1953). It is to be expected that experts and thinkers would write quite differently within this framework than in some other media for politically-relevant opinions. For example, the first Director of the Institute of Public Administration, Tom Barrington, presented a paper to officials of the European Commission in 1974 describing the Irish "realistic and pragmatic enthusiasm towards the European Community"1". Rather than the mix of "functionary" and "visionary" that I have outlined above, Barrington explains this pro-Europeanism as being a consequence of an education system that "discouraged the speculative and reinforced the natural bent towards the practical, the unintellectual, the nonspeculative". He described Irish pragmatism as involving "a short-term view of change, where it was necessary, [leading] to a number of ad hoc solutions", the aggregate of which "seemed to result in fragmentation and incomprehensibility". Such anti-intellectualism, this high-ranking civil servant warned, may well produce eagerness in response to European integration but it would not prepare the path for the long course of Ireland's EU membership.

Brigid Laffan and Jane O'Mahony's analysis of responses to European integration in the Irish administration - which they show to be often informal, agenda-driven and conceived on an ad hoc basis - might imply that Barrington's critique was fairly perceptive $e^{43}$. Yet arguably this is not so much a sign of nascent anti-intellectualism in Ireland but rather because there are sound and significant reasons for such Irish pragmatism. As O'Mahony and Delanty put it, the

manner in which the Irish became 'good Europeans' and have continued to embrace successive evolutions of European Union highlights the need for a small semiperipheral state to belong within a larger context ${ }^{44}$.

Secondly, Barrington failed to anticipate the ability of the Irish political and intellectual elite to merge a euro-in-the-hand pragmatism with high-fluting ideals - expediency and idealism are not necessarily incompatible. Indeed, the official reasoning behind accession to the EEC, i.e. fulfilment of Irish sovereignty, implies that there is simply no need for tension between normative and practical interests, indeed, that the two are conjoined. Thus, the Irish political elite, supported by public intellectuals, have keenly avoided presenting any tension between a Europe of equality and one of prosperity. Former Taoiseach, Garret FitzGerald, described the greatest challenge for the EU as being "how 
the Community can provide not merely a framework for the economic development of our Continent, but also a cultural and moral dimension that will enlarge the horizons of the parallel national and regional cultures ${ }^{45}$ ".

\section{Media: friend and foe} twentieth century was the shift from church to state in the 1960 s as the major institutional arena for intellectual activity, as identified by Liam O'Dowd ${ }^{46}$. O'Dowd also presciently noted that the trend Debray explored in his study of modern French intellectuals ${ }^{47}$ was also becoming evident in late twentieth-century Ireland, with the media's replacement of both church and state as the dominant cultural apparatus ${ }^{48}$. What have been the consequences of this process, which was hastened and cemented by economic transformation in Ireland? In Celtic Tiger Ireland, conventional intellectual paradigms (particularly from left-wing or Catholic quarters) became less visible and less welcome in the mainstream media. The representation of the intellectual in the public arena has become that of "commentator", "pundit" or, if the individual has academic credentials, "expert". The norm for intellectual contributions to political debate in the mainstream media is in a broadcast panel discussion or, at best, a brief opinion piece in a newspaper. With a few noble exceptions, contemporary scholarly publications do not seek to bring intellectual critiques and debates about contemporary society to a wide, cross-disciplinary readership. In fact, the few spaces for lively discussion of grand ideas about Irish nationalism, and occasionally European integration, are now mainly to be found on the internet ${ }^{49}$. Nevertheless, it is noticeable that many online discussions about these subjects are in response to opinion pieces in established publications, such as Fintan O'Toole writing in the Irish Times, and even the most adventurous writers appear to reserve their most considered ideas and insights for publishing in printed texts. The development of new media for communicating ideas has not been the only change to affect the role of public intellectuals in Ireland.

\section{Specialisation and categorisation}

Zygmunt Bauman warned of the perils posed by the professionalisation and specialisation of intellectuals for the integrity of intellectualism and for its duty towards enhancing public knowledge ${ }^{50}$. Such problems are becoming evident in the representation of intellectuals in the contemporary debate about European integration in Ireland. The assortment of commentators and experts who are willing to speak publicly on "Europe" in Ireland is fairly slim and the scope for their analysis is confined. Individuals with the knowledge and capacity to debate the subject of EU integration rarelyo get the opportunity to do so in a public realm, and when they do it is invariably in the context of a referendum on an EU treaty (either forthcoming or failed - there is little discussion after ratification). At such times, all broadcast contributions to the debate are categorised as being on one side or another. This is in part a consequence of the judgements of the Supreme Court in the cases of McKenna (1995) and Coughlan (2000) which ruled that referendum campaigns on EU treaties could not be funded by public monies, that a Referendum Commission would present the 'neutral' position and information about the treaty contents, and that "Yes" and "No" positions in referendum campaigns would have to be given equal time and fair presentation in the national media.

Études irlandaises, 34.2 | 2009 
21 As a consequence, there is no room for ambiguity or nuance, and certainly not for what Posner describes as intellectuals' crucial "respect for the complexity of problems ${ }^{51}$ ". Specialised intellectuals invited to speak on European integration are increasingly categorised as speaking either a "Yes" or "No" position. Among the effects of this, it is noticeable that EU lawyers are gaining more prominence in public debates (answering questions about the contents and effects of treaty articles rather than the reason for their inclusion) and that Irish social scientists with expertise on the EU are having to "pin their colours to the mast" if they even want to contribute to public knowledge of the subject. The subsequent representation of academics contributing to the national discussion about European integration is not one of a public intellectual in either the universal or specific sense, but one of a campaigner. This is a stark example of what Bourdieu laments as the current form of public intellectual work, namely "public position-taking", and it is one that any scholar who seeks to contribute to the "Europe" debate in Ireland is forced to take ${ }^{52}$.

\section{Conclusion}

By way of conclusion, I wish to summarise core points made above and then consider their implications for the representations of intellectuals in debates on and beyond European integration in Ireland. First, the preoccupation with national identity and nation-building among the Irish intelligentsia identified by O'Dowd is clearly evident in the contributions made by Irish intellectuals to the debate about "Europe ${ }^{53}$ ". Arguments made by intellectuals both in support and in criticism of European integration have ultimately centred on the process of imagining and constructing the Irish nation-state. Precisely because of this national crux, there has been a trend of turning a necessity into a virtue in pro-integrationist arguments. There has therefore always been a "functionary" element to most intellectual contributions on Ireland's relationship with the EU. However, this article has argued that in recent times this tendency has come to subjugate the "visionary" nature of intellectual contributions on the subject of European integration. This has occurred partly through the shrinking public "space" available to intellectuals, the increasing emphasis on "specialisation" and expertise, and the push for academics to be identified as "Yes" or "No" supporters in their contributions to the debate on "Europe". In such ways, the current context for discussing European integration in Ireland exemplifies the challenges faced by intellectuals seeking to contribute to public debate across contemporary political sphere.

The current "crisis" in Ireland's relationship with the EU reveals some of the dangers of confining intellectual imagination when it holds such importance for public conception and engagement with a powerful political entity. If Ireland's intellectual forebears depended on grandiose, idealised notions "Europe" in order to foster Irish enthusiasm for EEC membership, we have reached a critical point in needing them to be recovered and revived for the modern challenges of this age. It is possible to speculate that the decline of imagination about European integration is correlated with the similar downward trend in nationalist imagination itself - economism may be said to be the grand narrative to have replaced nationalism in the twenty-first century. Yet the results of the referendums on the Nice and Lisbon treaties are evidence that this technical, economistic, media-led discourse is insufficient to inspire a demos willing to support further European integration. An analysis of Irish public opinion about European integration shows still a 
lingering fondness for Europe but one that is not accompanied by much intense interest in it. Ireland's embracing of Europe has been an essentially a narcissistic affair, and it has been no less gratifying for that. But intellectuals need not concentrate on reshaping Irish nationalism in order to fit with European integration. Richard Kearney's analyses of "Europe", which are regrettably beyond the remit of this paper to dissect, are quite so engaging because he acknowledges that the continent is one of "metamorphosis", that it is subject to change, and that it is as Janus-faced as its nationalist foil ${ }^{54}$. Perhaps it is now possible to begin to reimagine "Europe" in line with the realities of global, as well as national, circumstance. Ireland's experience of EU membership would suggest that the "visionary" elements of intellectual conceptions of European integration are as essential as the "functionary" ones ${ }^{55}$.

\section{NOTES}

1. P. Bourdieu and J.-C. Passeron, Reproduction in Education, Society and Culture, trans. R. Nice, London, Sage, 1990 (1977) ; S. N., Eisenstadt, "Intellectuals and Tradition", Daedalus, vol. 101, n², 1972, p. 1 .

2. K. Hayward, Irish Nationalism and European Integration: The official redefinition of the island of Ireland, Manchester, Manchester University Press, 2009.

3. The first Irish referendum to ratify the Treaty of Nice was rejected by 53.9 percent of voters, on a turnout of 34.8 percent, in June 2001 (it was passed in a second referendum the following year). The first referendum on the Treaty of Lisbon, held in June 2008, was rejected by 53.4 per cent (on a turnout of 53.1 percent). At the time of writing, the second referendum on the Treaty of Lisbon was to be held on 2 October 2009.

4. B. Fanning, The Quest for Modern Ireland: The battle of ideas 1912-1986, Dublin, Irish Academic Press, 2008, p. 7.

5. D. Roche, "Ireland and the future of the EU", speech given at the re-launch of the Jean Monnet Centre of Excellence in European Studies, Queen's University Belfast, 23 February 2009.

6. P. O'Mahony, P. G. and Delanty, Rethinking Irish History: Nationalism, Identity and Ideology, Basingstoke, Macmillan, 1998, p. 175.

7. Ibid.

8. M. Goldring, Pleasant the Scholar's Life: Irish intellectuals and the construction of the nationstate, London, Serif, 1993, p. 175.

9. M. Goldring, Faith of our Fathers: A study of Irish nationalism, Dublin, Repsol, 1987.

10. T. Garvin, Preventing the Future. Why was Ireland so poor for so long? Dublin, Gill and Macmillan, 2005.

11. B. Fanning, op. cit., p. 4.

12. Ibid., p. 1.

13. J. Murray, J., “This Growing Sense of Europe”, Studies, vol. 41, n 163-4, 1952, p. 268. 
14. Ibid., p. 273 (emphasis added).

15. Ibid., p. 280.

16. Ibid.

17. W. J. Philbin, "The Irish and the New Europe", text of an address delivered by the Bishop of Clonfert to the Catholic Workers' College, Dublin, January 1962, published in Studies, vol. 51, n 21, p. 27-43 (emphases added).

18. T. F. Ó Raifeartaigh, Ireland and the EEC: The Cultural Aspects, Dublin, Irish Council of the European Movement, 1972, p. 6.

19. For example, see J. Murray, "The Spread of the Idea of Europe", Studies, vol. $47, \mathrm{n}^{\circ} 188$, 1958, p. 410-420 ; G. FitzGerald, "Political Implications of Irish Membership of the EEC", Studies, vol. 51, n² 201, 1962, p. 44-81.

20. For example, see G. Wylie, "The Future of the European Union. What, how and why?", Studies, vol. 91, n 362, 2002, p. 125-133.

21. For example, see G. Quinn, "Ireland and the European Monetary System", Studies, vol. 67, n² 268, 1978, p. 265-275 ; S. Murphy, "The New Europe and Irish Neutrality”, Studies, vol. 79, nº 316, 1990, p. 377-386.

22. R. Kearney, The Irish Mind: Exploring Intellectual Traditions, Dublin, Wolfhound Press, 1984, p. 8.

23. T. F. Ó Raifeartaigh, T. F., op cit.

24. G. FitzGerald, Towards a New Ireland (1972), Dublin, Torc Books, 1973.

25. G. FitzGerald, "The Common Market”, Irish Times, 5 January 1963.

26. Ibid.

27. T. F. Ó Raifeartaigh, op. cit., p. 13.

28. Ibid., p. 6-13.

29. Ibid., p. 4.

30. Ibid., p. 13.

31. For an example of this "visionary" thinking, see Michael D. Higgins' description of the Lisbon Treaty as, "an opportunity, a platform from which new policies and thinking, which recognise our global interdependency, our intergenerational responsibility and our ethical obligations to each other, can evolve". See Europe and the World: The European Union and the Lisbon Reform Treaty, article on Labour Party website, July 2009: [www.labour.ie/ lisbonreformtreaty/policy/europeandtheworld.html] (accessed August 2009).

32. For an example of his criticism of particular aspects of the EU's evolution, see M. D. Higgins, "Drifting Towards an Homogenized Future", Aisling Magazine, n²7, August 2000: [ www.aislingmagazine.com/aislingmagazine/articles/TAM27/Drifting.html] (accessed August 2009).

33. For more on intellectual opposition to EEC membership see A. Devenney, “'A Unique and Unparalleled Surrender of Sovereignty': Early Opposition to European Integration in Ireland, 1961-72", New Hibernia Review, vol. 12, nº 4, winter 2008, pp. 15-32.

34. P. Kirby, L. Gibbons and M. Cronin (eds.) Reinventing Ireland: Culture, Society and the Global Economy, London, Pluto, 2002.

35. A. Storey, "The European Project: Dismantling the social model, globalising neoliberalism", The Irish Review, vol. 34, pp. 20-33. 
36. Aodogan O'Rahilly - interview conducted by Gary Murphy and cited in G. Murphy, "Towards the Corporate State: Seán Lemass and the realignment of interest groups in the policy process, 1948-1964", Administration, vol. 47, n 1, 1999, p. 100.

37. Ibid.

38. D. Fennell, The Postwestern Condition: Between chaos and civilisation, London, Minerva Press, 1999 ; Ireland after the End of Western Civilisation, Belfast, Athol Books, 2009.

39. D. Fennell, About Behaving Normally in Abnormal Circumstances, Belfast, Athol Books, 2007.

40. T. Garvin, "Imaginary Cassandra?: Conor Cruise O'Brien as Public Intellectual in Ireland", Irish University Review: A Journal of Irish Studies, n 37, September 2007, p. 439.

41. T. J. Barrington quoted in B. Fanning, op. cit., p. 204.

42. Ibid.

43. B. Laffan and J. O'Mahony, Ireland and the European Union. Basingstoke, Palgrave Macmillan, 2008.

44. P. O'Mahony, P. and G. Delanty, op. cit., p. 175.

45. G. FitzGerald, "Ireland, Britain, Europe: Beyond Economic and Political Unity", in J. P. Mackey (ed.), The Cultures of Europe: The Irish Contribution, Belfast, Institute of Irish Studies, Queen's University Belfast, 1994, p. 185.

46. L. O'Dowd, “Intellectuals in Twentieth Century Ireland and the case of George Russell (Æ)", Crane Bag, n9, 1985, pp. 6-25.

47. R. Debray, Teachers, Writers and Celebrities: The Intellectuals of Modern France, trans. D. Macey, London, Verso, 1981.

48. L. O'Dowd, "A Sociological Introduction", in L. O'Dowd (ed.), On Intellectuals and Intellectual Life in Ireland: International, comparative and historical contexts, Belfast, Royal Irish Academy/Institute of Irish Studies, Queen's University Belfast, 1996, p. 1, p. 14.

49. The most fruitful sources of such non-party-political intellectual musing are blogs, by groups such as the think tank TASC [www.progressive-economy.ie/] or by individual Irish writers (literary, academic, journalistic or aspiring) such as [www.eire.com], and websites set up by motivated individual thinkers, such as Philip Casey [www.alternativeparty.org] or Ronit Lentin [www.ronitlentin.wordpress.com] (all sites accessed August 2009).

50. Z. Bauman, Life in Fragments: Essays in postmodern morality, Oxford, Blackwell, 1995.

51. R. Posner, Public Intellectuals: A Study of Decline, Cambridge, MA, Harvard University Press, 2001, p. 3.

52. P. Bourdieu, P., Acts of Resistance: Against the Tyranny of the Market, trans. R. Nice, New York, New Press, 1999.

53. L. O'Dowd, op. cit., p. 8.

54. R. Kearney, Visions of Europe: Conversations on the legacy and future of Europe, Dublin, Wolfhound Press, 1992, p. 7, p. 11; T. Nairn, Faces of Nationalism: Janus revisited, London, Verso, 1997.

55. Acknowledgements. I am very grateful to Liam O'Dowd, Colin D. Shaw, Tom Garvin and John Coakley for engaging and insightful conversations that helped define some of the thinking behind this paper. All errors and misjudgements are entirely attributable to the author. 


\section{ABSTRACTS}

As Ireland contemplated, and then became part of, the evolving European Community, Irish intellectuals played a central role in debating integration. This article assesses the representations of Irish intellectuals in relation to Ireland's EEC/EU membership and makes three core arguments. First, it seeks to show that intellectual contributions to the debate about European integration, both positive and negative, have been inseparable from the processes of imagining and constructing the Irish nation-state. Secondly, it argues that the mix of necessity and opportunity in Ireland's accession to the EEC has meant that there have always been "functionary" as well as "visionary" elements to intellectual contributions on this subject, but now the former has largely subjugated the latter. Finally, the current context for discussing European integration in Ireland exemplifies the challenges faced by intellectuals seeking to contribute to public debate across contemporary political sphere. The premise of this article is that the very requirement of a second referendum on the Lisbon Treaty reveals both the dire need for and the current constraints on intellectual visionary thinking about "Europe" in Ireland and beyond.

Depuis l'époque où l'Irlande envisageait de devenir membre d'une Communauté Européenne en évolution, puis après son adhésion, les intellectuels irlandais ont joué un rôle essentiel dans le débat sur l'intégration. Cet article étudie les représentations de l'adhésion à la CEE/UE véhiculées par les intellectuels irlandais et avance principalement trois arguments principaux. D'abord, il vise à démontrer que les apports, aussi bien positifs que négatifs, des intellectuels au débat sur l'intégration européenne, sont inséparables des processus par lesquels l'État-nation a été imaginé et construit. En second lieu, cet article affirme que le mélange de nécessité et d'opportunisme qui a présidé à l'adhésion de l'Irlande à la CEE se reflète dans les aspects «fonctionnels » aussi bien que les aspects « visionnaires » des contributions des intellectuels sur ce sujet, mais qu'à présent les premiers ont largement pris le pas sur les seconds. Enfin, le contexte actuel dans lequel se déroulent les discussions en Irlande sur l'intégration européenne illustre le défi que doivent relever les intellectuels qui souhaitent apporter une contribution au débat public dans la sphère politique contemporaine. L'un des présupposés de cet article est que la nécessité même d'un second référendum sur le Traité de Lisbonne reflète à la fois le besoin crucial d'intellectuels et les contraintes qui pèsent sur une approche visionnaire de l'Europe, en Irlande comme ailleurs.

\section{INDEX}

Keywords: intellectuals, European Union / EEC, public debate

Mots-clés: intellectuels, Union Européenne / CEE, débat public 
AUTHOR

KATY HAYWARD

Queen's University, Belfast 